\title{
CONSUMER MOTIVATIONS, ATTITUDE AND BEHAVIORAL INTENTION TOWARD GREEN HOTEL SELECTION
}

\author{
Lei Wang ${ }^{1^{\star}}$, Zi-Xu Wang ${ }^{2}$, Philip Pong Weng Wong ${ }^{3}$, Qi Zhang ${ }^{4}$ \\ 1,4Faculty of Hospitality and Tourism, School of Management, Xuzhou University of Technology, China \\ ${ }^{2}$ Business School, City University College of Science and Technology. \\ ${ }^{3}$ School of Hospitality, Sunway University, Malaysia. \\ *Corresponding author's email: 1136603668@qq.com
}

\begin{abstract}
Most prior studies have investigated the relationship between green purchase attitude and behavior based on the Theory of Planned Behavior (TPB). However, TPB is a behavioral theory based on a causal process, and thus ignores consumers' motivational aspects. The purpose of this study is to examine consumers' motivational variables, in which monetary, convenience (location), hedonic and virtual motivation (social media) influence consumers' intentions to visit green hotels based on generational characteristics. A survey questionnaire was developed where a total of 775 questionnaires were ultimately collected followed by subsequent empirical testing of the postulated hypotheses using SPSS and Structural Equation Modelling. The results suggest monetary and virtual motivation positively influence green purchase attitude (GPA) respectively, while convenience negatively influence GPA. GPA displays a positive influence on green purchase intention (GPI) while hedonic motivation plays no role in this study. In addition, statistically significant differences in monetary, convenience, hedonic, virtual motivation and GPI were observed between generations of consumers towards green hotel selection. The theoretical and practical implications of the results were highlighted, including limitations of the research. Lastly, this study addressed the relationship between motivational traits and behavioral intention in the hospitality and tourism field, and its results will provide useful information for green hotels' stakeholders.
\end{abstract}

Keywords: Monetary motivation; Convenience motivation; Hedonic motivation; Virtual motivation; green purchase attitude; intention; green hotel selection 


\section{INTRODUCTION}

Environmentally sustainability has been given increasing attention by consumers, business organizations, societies and governments in many countries (Nimri et al., 2019; Wang et al., 2020b), as rapid industrial development results in over-consumption of natural resources resulting in environmental pollution (Wang et al., 2020c). Hence, green purchase behavior (GPB) has spawned growing research interest (Wang \& Wong, 2020), and it has emerged as a new discipline in the realm of consumer behavior research (Rahman et al., 2020).

Sustainability is an important term in the leisure tourism context (Han et al., 2017), and sustainable tourism behavior is progressively recognized as a popular topic among youth travelers (Han et al., 2019). The tourism industry's rapid and consistent growth has been a major tool in the neoliberal globalization and shrinking of the planet, contributing to different environmental issues (Lew, 2020). Pro-environmentally minded tourists and environmentally friendly leisure activities are steadily increasing (Han et al., 2017), and the growing demand for sustainable tourism has instigated many changes in the leisure sector (Wang et al., 2020a). In line with this green trend, within the hotel industry, consumer demand for greener accommodation establishments have also increased (Wang et al., 2019).

According to the Green Hotel Association (2021), green hotels are environmentally friendly properties whose managers are eager to institute programs that save water, save energy and reduce solid waste, while saving money, to protect our planet earth. The hotel industry is one of the heaviest consumer of natural resources (Al-Aomar \& Hussain, 2017), and the trend of implementing pro-environmental programs is increasing in the hotel sector to reduce the negative environmental impacts associated with excessive consumption (Nimri et al., 2019; Wang et al., 2019).

Certain studies have shown that consumer psychographic characteristics such as environmental concern (Han et al., 2019), environmental knowledge (Wang et al., 2020a), environmental value (Kumar \& Sreen, 2020), environmental consciousness (Bashir et al., 
2019), and perceived consumer effectiveness (Rahman et al., 2020) influence the GPB decision-making process based on the theory of planned behavior (TPB). However, the results from earlier studies are, by no means conclusive and can even be considered controversial (Wang, 2020). While psychographic traits are seen as important variables in such studies, inconsistent outcomes have meant that the results are not useful for predicting consumer GPB.

One of the criticisms of adopting those psychographic traits is its focus on rational reasoning and its lack of consideration on subconscious and impulse factors, as propagated in the TPB model (Sniehotta et al., 2014). Travel motivation research is the starting point for any attempt to obtain an understanding of a tourist's behavior (Ulker-Demirel \& Ciftci, 2020). According to Testa et al. (2020), price and emotional aspects are the external issues that can hinder or support one's GPB. Few studies actually addressed the relationship between motivational traits and behavioral intention in the hospitality and tourism field (Ulker-Demirel \& Ciftci, 2020).

Furthermore, variances in GPB behavior among the different generations still remain under-researched (Ulker-Demirel \& Ciftci, 2020). Therefore, there is a research gap in the hospitality and tourism literature related to studies on the GPB of different generations, which focuses on motivational, attitudinal factors and their green behavioral intention (GPI) (UlkerDemirel \& Ciftci, 2020).

In addition, studies conducted on GPB are still not well investigated in Asian countries like China (Rahman et al., 2020). Research on environmentally friendly hotels is still in its preliminary stage in China, where empirical studies revealed low levels of concern and understanding among Chinese consumers (Wang et al., 2020a). Furthermore, most of the existing studies were developed and tested using samples from western societies (Wang \& Wong, 2020). There are limited findings on the environmentally friendly hotel selection in Asian countries where the systemic framework is weak in this particular research field (Wang et al., 2019).

This study sets out to examine the impact of motivational factors: monetary, convenience (location), hedonism and virtual motivation (social media) on Chinese consumer 
green purchase attitude (GPA) and GPI toward green hotels' selection. In addition, this study also seeks to investigate if there are variation in the GPB of different generations in their selection of environmentally friendly hotels.

\section{Hypothesis Development}

\section{External Motivation-Attitude-Behavior}

According to Miao and Wei (2013), prior studies suggested that internal and external motivational distinction provides a theoretical lens through which various pro-environmental behaviors in green marketing can be examined. Internal motivation refers to the broad motives that result in an individual participating in a whole set of behaviors (e.g., struggling to live an environmentally friendly lifestyle) (Miao \& Wei, 2013). Many studies explored the motivation of tourists from the impact of the internal characteristics on one's attitude and behavior in tourism literature (e.g., psychological traits) (Ulker-Demirel \& Ciftci, 2020). Some studies demonstrated that internal pro-environmental motivation (e.g., environmental concern, biospheric values) even plays an effective role in promoting positive behavior and increasing one's psychological well-being rather than one's external motivations (Jena \& Behera, 2017; Mahmood et al., 2019).

However, there are some external motivational barriers to pro-environmental behavior which are more intense and have a different effect on the consumer (Jena \& Behera, 2017). For example, a tourist will patronize a particular green hotel because it is convenient (i.e., location) for her to visit major travel attractions. In this example, the external motivation (i.e., location) overrides the internal motivation (i.e., environmental beliefs, values, psychological traits). Therefore, external motivations are more immediate and revolve around an individual's own needs (Miao \& Wei, 2013). Non-environment external motivations, such as a desire for fun (hedonic motivation), a desire for good locations (convenience motivation), a desire to save money (monetary motivation) or a desire to maintain a virtual relationship (virtual motivation) are considered external motivations. 


\section{Monetary Motivation}

Price refers to the monetary value one must give in exchange for a product or service (Yeo et al., 2017). Price consciousness plays a major role in an individual's purchase decision, as there is a relationship between product/service quality and price (Rajendran et al., 2019). Price consciousness for a product/service varies for each individual (Razali et al., 2019), because individuals prefer to purchase the product/service that offers the best perceived value (Rajendran et al., 2019).

The influence of monetary motivation on certain behaviors is recognized, but only a few studies empirically tested the role of monetary motivation as a precondition to comprehend GPA and GPI pertaining to green hotels selection. Green price consciousness is an important element of the green marketing tools (Ibnou-Laaroussi et al., 2018). A green product/service is generally considered to be more expensive because of its pro-environmental and safety attributes, which is perceived to be less damaging to the environment. According to Razali et al. (2019), consumers in western countries are more likely to visit and display a strong willingness to pay more for a green hotel that practices green strategies; while Wang et al. (2020b) demonstrated that about $40 \%$ of consumers are willing to pay more to stay at green hotels. Hence, the following hypothesis was developed for testing:

H1: Monetary motivation significantly influences GPA.

\section{Convenience Motivation (Location)}

For the hotel sector, convenience motivation represents the accessibility of the services/facilities provided to the consumers (Teng et al., 2020). The choice of location is one of the key economic decision for hotel operators, because it strongly influences the consumer decision-making process, and a good location determines the hotel's profitability and developmental prospects (Puciato, 2020). It allows the consumers to have the convenience of time and place related to the various elements of their travels.

Certain studies on the behavioral aspects of convenience motivation have only addressed industrial companies' perspectives and indicated its significance. However, there 
is a lack of studies on tourism market entities including hotels (Puciato, 2020). The term "green hotel" is relatively new to the Chinese, and various industry research reports and studies revealed low levels of concern and understanding of environmentally friendly hotels. For example, Wang et al. (2020c) found that there were only two green hotels operating in Xi'an city, China, although Xi'an is a world-famous tourism destination.

Convenience motivation appears to have a significant value in an individual's travel decision in tourism literature. For instance, Puciato (2020) found the importance of location in the selection of independent hotels among Polish consumers. According to Mohamad et al. (2014), convenience was found to significantly influence consumer's decision to visit green hotels in Malaysia. Moreover, Yang et al. (2012) highlighted the high explanatory power of convenience motivation as a determinant of business travelers' attitude in China. Thus, the following hypothesis was tested:

H2: Convenience motivation significantly influences GPA.

\section{Hedonic Motivation}

Hedonic motivation is considered as a function value in the Goal-Framing theory (Lindenberg \& Steg, 2007). According to Yeo et al. (2017), shopping for goods or products has been viewed as a rational process from a utilitarian perspective. In contrast, hedonic motivation is an irrational process which may be viewed as the desire to feel better (Lindenberg, 2001) or the desire to have fun and be playful in the tourism literature (Rezaei et al., 2016). Hedonism may be involved two aspects: to increase/decrease arousal and increase/decrease pleasantness (Lindenberg, 2001). When consumers search for a particular product/service, they also seeking expected sensory stimulation, comfort, affection, symbolism, and status during the purchasing process (Yeo et al., 2017). Lindenberg (2001) stated that hedonic motivation may exist in almost everything people do, and it has been identified as the main precondition for the effect of mood. Hedonic motivation cannot replace the traditional consumption theories, rather, it works as a supplementary condition to enhance the cognitive-rational process (Yeo et al., 2017). 
Although many studies efforts have explored hedonic motivation underlying tourists' behaviors (Bilgihan, 2016; Rezaei et al., 2016), there is still space for further investigation of factors influencing environmentally friendly hotels selection. Miao and Wei (2013) found that hedonic motivation is the most important determinant in selecting a green hotel, where personal comfort and enjoyment are strongest predictors. According to Sánchez-Ollero et al. (2014), hedonic motivation was found to positively influence consumer GPA towards selecting green hotels. In addition, Peng and Chen (2019) reported a positive relationship between perceived hedonic risk and tourist hesitation, leading to intention to visit green hotels. Based on above findings, the following hypothesis is proposed:

H3: Hedonic motivation significantly influences GPA.

\section{Virtual Motivation (Social Media)}

The Social Capital Theory showed that social media has significant value in influencing an individual's structural and cognitive process due to its ability to help group members to achieve common goals and personal benefits (Mahmood et al., 2019). Social media can be considered as a medium through which collaboration and relationships with others is promoted (Fukuyama, 2002; Mahmood et al., 2019). According to Tanford et al. (2020), social media, such as Instagram and Facebook are powerful channels to share information, and the usergenerated content in social media is one of the main determinants of decision-making for certain individuals (Ulker-Demirel \& Ciftci, 2020; Ye et al., 2011). The combined usage of images and photos on such social media are more likely to produce an instant emotional response in consumers (Tanford et al., 2020).

Although some scientists recognized the important role of social media in consumer decision-making process, the tourism literature seems to be dominated by studies which are limited to tourists' purchase intention through technology based services (Ulker-Demirel \& Ciftci, 2020). Tanford et al. (2020) showed that random information from social media can influence the booking of a hotel, and Ulker-Demirel and Ciftci (2020) reported social media is of utmost important for hospitality and tourism businesses as it can create a severe shift in 
behavior by consumers. In green marketing, social media also plays a significant role in disseminating the importance of environmental awareness to the targeted consumers, where it can distribute persuasive and appealing information about the consumption of green products (Jan et al., 2019). Jan et al. (2019) reported that a higher virtual motivation (media exposure) resulted in an increase in positive GPA. Likewise, Tanford et al. (2020) showed social media positively affected consumers' evaluations of a sustainable hotel. Therefore, it was hypothesized that:

H4: Virtual motivation significantly influences GPA.

\section{GPA towards GPI}

Attitude refers to an individual's evaluation of a particular behavior (Wang \& Wong, 2020), and it is reflected in an individual's favorable or unfavorable evaluations, tendencies and feeling towards any given behavior or idea (Wang et al., 2020a). In green marketing, among the internal factors, one of the most relevant determinant is the attitude towards the natural environment (Ibáñez et al., 2020). According to Wang et al. (2019), GPA is defined as an individual's value judgement and it is related to the cognitive assessment on the importance of environmental protection. A greater concern for green products or services has resulted in consumers developing a positive GPI and participate in pro-environmental activities (Wang et al., 2020c).

Many studies on green hotel selection have showed how GPA positively affects GPI or GPB (Sutikno et al., 2020; Wang \& Wong, 2020). Zahan et al. (2020) adopted the TPB model and found that GPA positively affected GPI in selecting green housing among Bangladeshi consumers and Sutikno et al. (2020) reported similar results in Indonesia. Meanwhile, Wang et al. (2020b) discovered a positive relationship between GPA and GPI in China. In line with the findings of these previous studies, the following hypothesis was proposed:

H5: GPA positively influences GPI. 


\section{Generations X, Y, Z and Its Impact}

Ulker-Demirel and Ciftci (2020) indicated that research on GPB among the different generations appear to be lacking in the hospitality and tourism literature. One possible reasons may be that such studies in the past have shown inconsistent and even contradictory findings (Wang et al., 2020b). Another possible reason is that the early studies on generational differences used data which dates back to the early nineties (Ulker-Demirel \& Ciftci, 2020). A generation is a group of individuals who are born in a certain period of time, and they are influenced by historical events and cultural phenomena which they encountered during certain periods in their lives (Kusumawati et al., 2019). Differences in purchasing behavior were identified among the three generations, namely Generation X, Y, and Z (Wiratno et al., 2020) and each generation were found to have their own characteristics.

Generation X (Gen X) includes those born between 1960 and 1980 (Bencsik et al., 2016). Gen X possesses a certain mentality for consumerism (Wiratno et al., 2020), leaving no space for idealism because they have numerous financial needs and constraints, hence, they often shop at value-oriented retail providers (Kusumawati et al., 2019). Gen X tends not to be loyal to a particular brand or company, and is often characterized by high levels of skepticism, and marketers must focus on building a strong level of trust to attract them (Kusumawati et al., 2019). They are willing to pay a high price as long as the quality is equal to the price and while Gen X consumers may search for information related to certain products/services online, their purchasing behaviors is still mainly conducted offline (Wiratno et al., 2020).

Generation Y (Gen Y) includes those born between 1980 and 1995 (Bencsik et al., 2016), and is identified as the Millennials (Oczachowska, 2020). Gen $Y$ is labelled as being independent, selfish and strongly autonomous (Kusumawati et al., 2019), and this is reflected in their individual approach to everything, including an attitude that is based on emotions and feelings (Oczachowska, 2020). Knowledge obtained by Gen $Y$ consumers allows them to make the best and most economic purchase (Oczachowska, 2020), and they tend to look for a particular brand or company that connects them with friends with the same preferences. (Kusumawati et al., 2019). Gen Ys were born during the emerging technology era, and 
technology is part of their everyday life (Kusumawati et al., 2019) and they are known as digital natives. They most frequently search for information about products or services they want online (e.g., Facebook, Twitter), and also to make a purchase (Wiratno et al., 2020).

Generation Z (Gen Z) includes those born between 1995 and 2010 (Bencsik et al., 2016), and they have never lived without the internet (Kusumawati et al., 2019). Wiratno et al. (2020) showed this generation has an open mind, and are spontaneous in expressing their feelings and thoughts. They are not afraid of continuous changes and new challenges, and are more impatient and more agile than Gen $X$ and $Y$ to a certain extent (Bencsik et al., 2016). Gen $Z$ is highly influenced by new media, virtual friends, and the power that comes with new technology (Kusumawati et al., 2019), because they are generally well educated and well connected, and utilize existing technologies to acquire the products/services they want (Wiratno et al., 2020).

Previous studies have highlighted a significant causative path among different generations between GPA and GPI in tourism literature. For instance, Wang et al. (2020b) found that Gen $Y$ (age of $18-30$ ) has a higher level of GPI compared to Gen $Z$ (below the age of 18) to visit green hotels in China. Kim et al. (2012) reported Gen Y (age of $25-35$ ) are more likely to stay at green hotels than consumers who belong to Gen X (above the age of 55). Another study by Goh and Jie (2019) found that Gen Z has a negative attitude towards food wastage in hotel sector. Hence, the following hypothesis were proposed:

H6 (a-f): There is a significant difference between Generation $X, Y$, and $Z$ towards monetary motivation (H6a), convenience motivation (H6b), hedonic motivation (H6c), virtual motivation (H6d), GPA (H6e), and GPI (H6f) to visit environmentally friendly hotels respectively. 


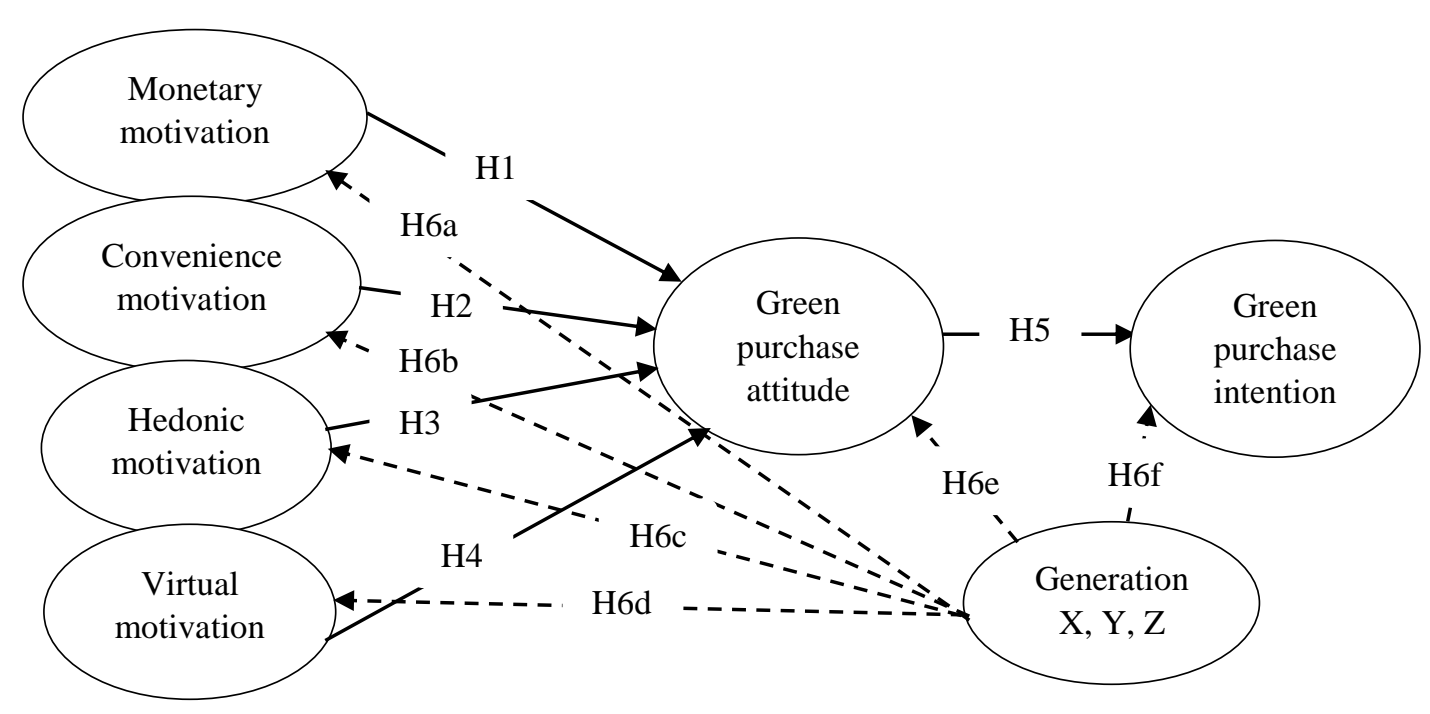

Figure 1. Conceptual Research Model

\section{METHODOLOGY}

\section{Sample and Data Collection}

A non-probability sampling method was adopted for this study as it is challenging for social science studies of this nature to acquire a precise sampling frame (Saunders et al., 2011). A purposive sampling technique was selected to collect data, as it allows researchers to exercise self-judgement in selecting cases that would best fit their research objectives and enable them to answer the research questions accurately (Wang et al., 2020c).

A total of 1200 questionnaires were distributed to domestic tourists who are staying or having stayed at four green hotels in Xuzhou: New Century Grand Hotel; HanYuan Hotel; Jiali International Hotel; and JinLing Hotel between 30 June and 31 August 2020, and between 1 April and 5 May 2021. All the questionnaires were distributed to customers by researchers manually (i.e., onsite interception in F\&B outlets and at the reception area). An explanation of the survey and study was provided to consumers during the interception period, while the consumers' participation in the survey was voluntary. Indeed, anonymity is guaranteed to all participations.

According to the recommendation by Sekaran (2006), a recommended sample size for most studies should exceed 30 but less than 500 respondents. For SEM, most studies 
suggested a sample size of at least 200 respondents, with 10 to 20 cases per parameter (Kline, 2015; Tabachnick \& Fidell, 2012). Furthermore, based on a widely used Cochran formula for an unknown number of the target population, a minimum sample size of 384 respondents is recommended (Burstein, 2011; Sarmah et al., 2013). For this study, 831 respondents were gathered, and after eliminating the questionnaires with missing values, 775 usable questionnaires were analysed (64.6\% response rate). A pilot test that involved 30 respondents was performed to ensure the usability and validity of the developed instrument and to prevent any problems that may affect the quality of the obtained data.

\section{Measurement and Survey Questionnaire Development}

The self-administered questionnaire for this study consists of well-established, closedended items and incorporated validated measurement scales. The questionnaire was designed in three sections. The first section included the exogenous variables: monetary, convenience, hedonic and virtual motivation. Three items used to measure monetary motivation were adopted from Tan et al. (2020); five items used to measure convenience motivation were adapted from Puciato (2020); three items used to measure hedonic motivation were adapted from Yeo et al. (2017); and six item used to measure virtual motivation were adapted from Jan et al. (2019) and Zolait and Sulaiman (2009).

The second section included the endogenous variables: GPA and GPI. Four items belonging to GPA were adopted from Wang and Wong (2020), whereas four items belonging to GPI were adopted from Wang et al. (2020b). The last section of the questionnaire included the demographic characteristics: age (Generation X, Y, Z), gender, income and education level. All items of questionnaire were evaluated using a five-point Likert scale, from strongly disagree to strongly agree, since a five-point Likert scale is able to produce marginally higher mean scores and making data comparison a much easier process (Dawes, 2008). In addition, all items of the questionnaire were translated into Chinese using the back-translation method. 


\section{DATA ANALYSIS AND RESULTS}

SPSS 19 was utilized for the descriptive statistics and analysis of variance for this study while confirmatory factor analysis (CFA) and structural equation modelling (SEM) tests were performed using AMOS.

\section{Descriptive Analysis}

Table 1 shows the descriptive statistics for demographic characteristics for samples. From the 555 respondents, most of the respondents were male (63.1\%) and belonged to Gen Y (67.4\%). Furthermore, 41.3 percent of them earned between 3001 - 4500 CNY (Chinese Yuan) per month, and 48.1 percent have completed a 4-year bachelor's degree.

Table 1. Sample Characteristic $(N=775)$

\begin{tabular}{|c|c|c|c|}
\hline Items & Characteristic & Frequency & Percentage (\%) \\
\hline \multirow{3}{*}{ Gender } & Male & 296 & 38.2 \\
\cline { 2 - 4 } & Female & 479 & 61.8 \\
\hline \multirow{4}{*}{ Inceneration } & Gen X (1960-1980) & 102 & 28.4 \\
\cline { 2 - 4 } & Gen Y (1980-1995) & 453 & 58.5 \\
\cline { 2 - 4 } & Gen Z (1995-2010) & 220 & 13.2 \\
\cline { 2 - 4 } & Below 1700 & 163 & 21.0 \\
\cline { 2 - 4 } & $1701-3000$ & 125 & 16.1 \\
\cline { 2 - 4 } & $3001-4500$ & 218 & 28.1 \\
\cline { 2 - 4 } & $4501-6000$ & 152 & 19.6 \\
\cline { 2 - 4 } & Above 6001 & 117 & 15.1 \\
\cline { 2 - 4 } & Middle School & 48 & 6.2 \\
\cline { 2 - 4 } & High School & 59 & 31.4 \\
\cline { 2 - 4 } & Diploma & 243 & 47.6 \\
\cline { 2 - 4 } & Bachelor & 369 & 7.2 \\
\cline { 2 - 4 } & Masters and above & 56 & \\
\hline
\end{tabular}

\section{Confirmatory Factor Analysis}

For assessing the reliability of this research, Hair et al. (2010) suggested a Cronbach's Alpha value of 0.7 and above as acceptable (See Table 2). According to Hair et al. (2010), the rule of thumb for assessing the practical significance of standardised factor loadings must be at least 0.5 or higher; ideally 0.7 or higher. For the convergent validity of the measurement model, the composite reliability $(\mathrm{CR})$ should be greater than 0.7 , and the average variance extracted (AVE) should be greater than 0.5 (Hair et al., 2010). After dropping off the factor loadings below 0.65 (i.e., Convenience1, 5, Intention4, Virtual motivation1, 2, 6), the validity 
and reliability of the remaining items were established (See Table 2).

Table 2. Construct Validity

\begin{tabular}{|c|c|c|c|c|c|}
\hline $\begin{array}{c}\text { Construct } \\
\text { (Cronbach's } \\
\text { Alpha) }\end{array}$ & Item & $\begin{array}{c}\text { Item } \\
\text { loading }\end{array}$ & CR & AVE & SD \\
\hline $\begin{array}{l}\text { Monetary } \\
\text { motivation ( } \alpha \\
=0.877 \text { ) }\end{array}$ & $\begin{array}{l}\text { PC1. The relative monetary cost of green } \\
\text { service is moderate } \\
\text { PC2. The price of visiting a green hotel } \\
\text { would be perceived acceptable } \\
\text { PC3. Green hotels do offer good value for } \\
\text { money }\end{array}$ & $\begin{array}{l}0.710 \\
0.757 \\
0.731\end{array}$ & 0.777 & 0.537 & $\begin{array}{l}1.258 \\
1.250 \\
1.207\end{array}$ \\
\hline $\begin{array}{l}\text { Convenience } \\
\text { motivation ( } \alpha \\
=0.811 \text { ) }\end{array}$ & $\begin{array}{l}\text { CM2. The current location of the green hotel } \\
\text { is only one taken into account } \\
\text { CM3. The location of green hotels is the } \\
\text { most important factor for me } \\
\text { CM4. My decision of choosing green hotels } \\
\text { result from some stimulating activities } \\
\text { undertaken by local or regional authorities }\end{array}$ & $\begin{array}{l}0.666 \\
0.757 \\
0.767\end{array}$ & 0.775 & 0.535 & $\begin{array}{l}1.228 \\
1.197 \\
1.148\end{array}$ \\
\hline $\begin{array}{l}\text { Hedonic } \\
\text { motivation }(\alpha \\
=0.817)\end{array}$ & $\begin{array}{l}\text { HM1. I find that patronizing green hotel is } \\
\text { fun } \\
\text { HM2. I find that patronizing green hotel is } \\
\text { enjoyable } \\
\text { HM3. I find that patronizing green hotel is } \\
\text { very entertaining }\end{array}$ & $\begin{array}{l}0.804 \\
0.861 \\
\\
0.815\end{array}$ & 0.866 & 0.684 & $\begin{array}{l}1.353 \\
1.374 \\
\\
1.273\end{array}$ \\
\hline $\begin{array}{l}\text { Virtual } \\
\text { motivation }(\alpha \\
=0.809)\end{array}$ & $\begin{array}{l}\text { VM3. Media suggests visiting green hotels } \\
\text { is good idea } \\
\text { VM4. Media consistently recommend } \\
\text { visiting green hotels } \\
\text { VM5. For my profession, it is advisable to } \\
\text { visit green hotels and enjoy services }\end{array}$ & $\begin{array}{l}0.758 \\
0.814 \\
0.774\end{array}$ & 0.825 & 0.612 & $\begin{array}{l}1.126 \\
1.185 \\
1.206\end{array}$ \\
\hline $\begin{array}{l}\text { Green } \\
\text { purchase } \\
\text { attitude }(\alpha= \\
0.913)\end{array}$ & $\begin{array}{l}\text { For me, stay at a green hotel when } \\
\text { travelling is } \\
\text { GPA1. Desirable } \\
\text { GPA2. Pleasant } \\
\text { GPA3. Wise } \\
\text { GPA4. Positive }\end{array}$ & $\begin{array}{l}0.843 \\
0.882 \\
0.818 \\
0.843\end{array}$ & 0.910 & 0.717 & $\begin{array}{l}1.027 \\
1.021 \\
0.988 \\
1.036\end{array}$ \\
\hline $\begin{array}{l}\text { Green } \\
\text { purchase } \\
\text { intention }(\alpha= \\
0.86)\end{array}$ & $\begin{array}{l}\text { GPI1. I am willing to stay at a green hotel } \\
\text { when travelling } \\
\text { GPI2. I will make an effort to stay at a green } \\
\text { hotel when travelling } \\
\text { GPI3. I am likely to stay in a hotel } \\
\text { implementing environmental strategies }\end{array}$ & $\begin{array}{l}0.805 \\
0.851 \\
0.796\end{array}$ & 0.858 & 0.669 & $\begin{array}{l}1.196 \\
1.203\end{array}$ \\
\hline
\end{tabular}

The discriminant validity was assessed by considering the maximum shared squared variance (MSV), and the average shared squared variance (ASV) which should be less than AVE (Byrne, 2016; Hair et al., 2010). Meanwhile, the correlation between the different variables must be less than 0.9 in the measurement model (Meyers et al., 2006). Thus, the discriminant validity was established (See Table 3). 
Table 3. Discriminant Validity

\begin{tabular}{|l|c|c|c|c|c|c|c|c|c|}
\hline \multicolumn{1}{|c|}{ Research items } & 1 & 2 & 3 & 4 & 5 & 6 & AVE & MSV & ASV \\
\hline 1. Virtual motivation & $\mathbf{0 . 7 8 2 ^ { \mathrm { a } }}$ & & & & & & 0.612 & 0.526 & 0.195 \\
\hline $\begin{array}{l}\text { 2. Monetary } \\
\text { motivation }\end{array}$ & 0.226 & $\mathbf{0 . 7 3 3}$ & & & & & 0.537 & 0.288 & 0.148 \\
\hline $\begin{array}{l}\text { 3. Hedonic } \\
\text { motivation }\end{array}$ & 0.344 & 0.423 & $\mathbf{0 . 8 2 7}$ & & & & 0.684 & 0.448 & 0.175 \\
\hline $\begin{array}{l}\text { 4. Convenience } \\
\text { motivation }\end{array}$ & 0.725 & 0.322 & 0.317 & $\mathbf{0 . 7 3 1}$ & & & 0.535 & 0.526 & 0.176 \\
\hline 5. Attitude & 0.101 & 0.342 & 0.176 & -0.01 & $\mathbf{0 . 8 4 7}$ & & 0.717 & 0.117 & 0.051 \\
\hline 6. Intention & 0.520 & 0.537 & 0.669 & 0.385 & 0.309 & $\mathbf{0 . 8 1 8}$ & 0.669 & 0.448 & 0.250 \\
\hline
\end{tabular}

Note: a denotes square root of AVE.

Next, the model fit was assessed. In the model fit summary, the $X^{2}=304.433$, df $=131$, $\mathrm{p}<0.001$, the Chi-square divided by the df value (CMIN/DF) was 2.324, which was below 5.0, and therefore, accepted as an acceptable model (Hair et al., 2010). Besides, GFI = 0.961, CFI $=0.981, \mathrm{AGFI}=0.943, \mathrm{PGFI}=0.663, \mathrm{NFI}=0.966, \mathrm{IFI}=0.981, \mathrm{TLI}=0.975, \mathrm{RMR}=0.04$, PNFI $=0.74, \mathrm{PCFI}=0.751, \mathrm{RMSEA}=0.041$. Based on Ho (2006)'s suggestion that recommended thresholds for at least three indices must be met in order to ensure model fit, model fit in this research was achieved.

\section{Structural Model Estimation}

The next step was to perform SEM using the structural model to test the hypotheses. The overall goodness-of-fit indices of the structural model were: $X^{2}=803.627, \mathrm{df}=136, p<$ $0.001, \mathrm{CMIN} / \mathrm{DF}=5.909, \mathrm{AGFI}=0.869, \mathrm{PGFI}=0.649, \mathrm{CFI}=0.925, \mathrm{GFI}=0.906, \mathrm{NFI}=0.912$, $\mathrm{IFI}=0.925, \mathrm{TLI}=0.906, \mathrm{PNFI}=0.725, \mathrm{PCFI}=0.736, \mathrm{RMSEA}=0.08$. The values showed $\mathrm{a}$ good fit with the structural model and the outcomes tabulated. 


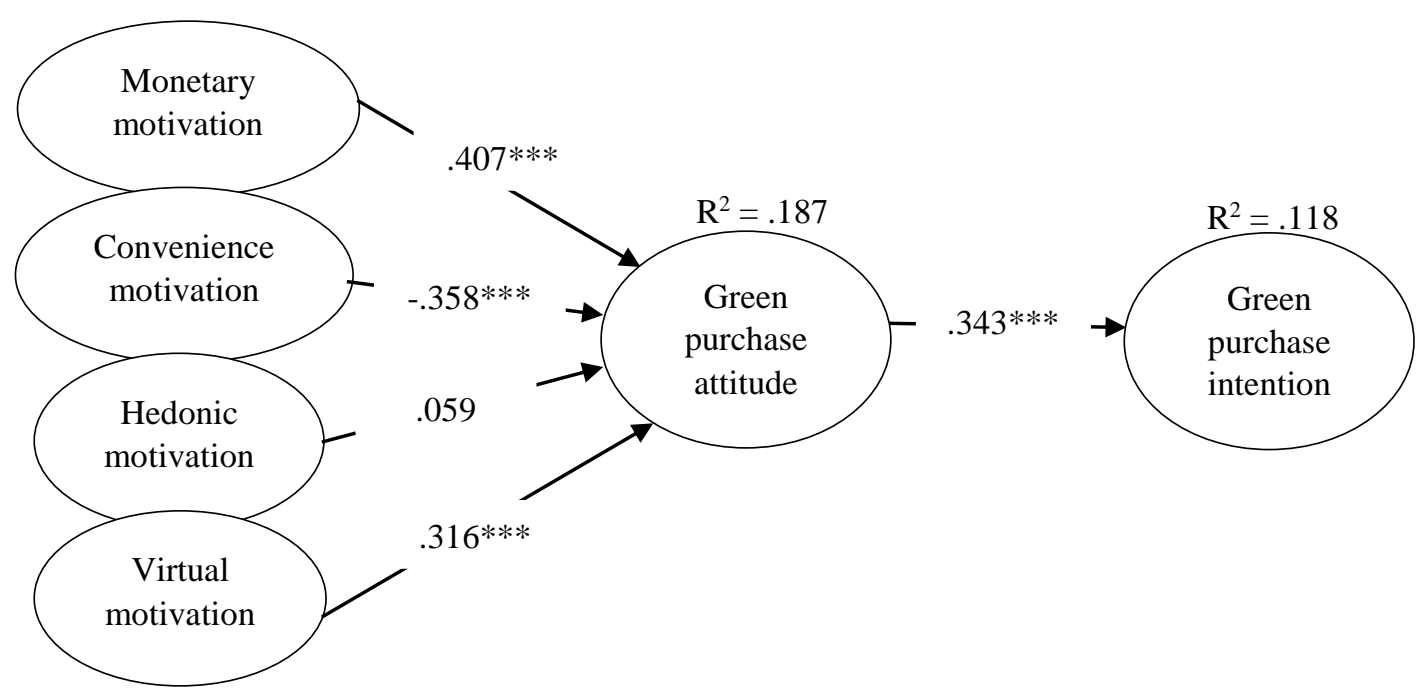

Note: ${ }^{*} \mathrm{p}<0.05,{ }^{* *} \mathrm{p}<0.01,{ }^{* * *} \mathrm{p}<0.001$, Critical ration (C.R.) $>1.96$

Figure 2. The Structural Model Outcomes

Table 4. Structural Relationships and Hypotheses Testing

\begin{tabular}{|c|l|c|c|c|c|}
\hline Items & \multicolumn{1}{|c|}{ Parameter } & $\beta$ & p-value & C.R. & Decision \\
\hline H1 & Monetary motivation --> GPA & 0.407 & ${ }^{* * *}$ & 8.147 & Supported \\
\hline H2 & $\begin{array}{l}\text { Convenience motivation ---> } \\
\text { GPA }\end{array}$ & -0.358 & ${ }^{* * *}$ & -4.910 & $\begin{array}{c}\text { Partially } \\
\text { supported }\end{array}$ \\
\hline H3 & Hedonic motivation ---> GPA & 0.059 & 0.190 & 1.309 & Not supported \\
\hline H4 & Virtual motivation ---> GPA & 0.316 & ${ }^{* * *}$ & 4.480 & Supported \\
\hline H5 & GPA ---> GPI & 0.343 & ${ }^{* * *}$ & 8.441 & Supported \\
\hline
\end{tabular}

\section{ANOVA Test}

The last step was to perform ANOVA test to analysis the influence of the different variables on the different generations under study. Table 5 displays the results of a one-way ANOVA and a Scheffe Alpha test was performed to classify the difference between the generation groups as shown in Table 6 .

Table 5. One-way ANOVA Samples Test

\begin{tabular}{|l|c|c|c|c|c|c|}
\hline \multicolumn{1}{|c|}{ Between Groups } & Factor & $\begin{array}{c}\text { Sum of } \\
\text { squares }\end{array}$ & $\mathrm{df}$ & $\begin{array}{c}\text { Mean } \\
\text { square }\end{array}$ & $\mathrm{F}$ & Sig. \\
\hline Monetary motivation & Generation & 33.454 & 2 & 16.727 & 16.388 & .000 \\
\hline Hedonic motivation & Generation & 72.557 & 2 & 36.279 & 27.682 & .000 \\
\hline $\begin{array}{l}\text { Convenience } \\
\text { motivation }\end{array}$ & Generation & 239.054 & 2 & 119.527 & 179.944 & .000 \\
\hline Virtual motivation & Generation & 195.343 & 2 & 97.717 & 127.669 & .000 \\
\hline $\begin{array}{l}\text { Green purchase } \\
\text { intention }\end{array}$ & Generation & 62.036 & 2 & 31.018 & 30.901 & .000 \\
\hline
\end{tabular}


Table 6. Post Hoc Tests of Monetary, Convenience Motivation, and GPI.

\begin{tabular}{|l|c|c|c|c|c|}
\hline \multicolumn{1}{|c|}{ Dependent variable } & $\begin{array}{c}(\mathrm{I}) \\
\text { Generation }\end{array}$ & $(\mathrm{J})$ Generation & $\begin{array}{c}\text { Mean } \\
\text { difference (I-J) }\end{array}$ & $\begin{array}{c}\text { Std. } \\
\text { error }\end{array}$ & Sig. \\
\hline Monetary motivation & Gen X & Gen Z & -0.573 & .121 & .000 \\
\hline & & Gen Y & -0.418 & .083 & .000 \\
\hline Hedonic motivation & Gen X & Gen Z & -.685 & .137 & .000 \\
\hline & & Gen Y & -.677 & .094 & .000 \\
\hline Convenience motivation & Gen X & Gen Z & -.947 & .098 & .000 \\
\hline & & Gen Y & -1.269 & .067 & .000 \\
\hline & Gen Z & Gen Y & -.322 & .089 & .002 \\
\hline Virtual motivation & Gen X & Gen Z & -.953 & .105 & .000 \\
\hline & & Gen Y & -1.140 & .072 & .000 \\
\hline Green purchase intention & Gen X & Gen Z & -.670 & .120 & .000 \\
\hline & & Gen Y & -.617 & .082 & .000 \\
\hline
\end{tabular}

An analysis of variance showed that the effect of generation on monetary motivation was statistically significantly, $F(2,772)=16.388, p<0.001$ values. Then, a Scheffe post hoc test revealed that the Gen $Y$ and $Z$ group, regarding monetary motivation, was statistically higher than the Gen X group respectively, $\mathrm{p}<0.05$ values. The mean difference $(I-J)$ between the generation of Gen $Y$ and Gen $X$ was 0.418 , the mean difference (I-J) between the generation of Gen $Z$ and Gen X was 0.573 . The Gen $Y$ and $Z$ group has a higher level of monetary motivation compared with Gen X group.

The results revealed that the effect of generational influence on hedonic motivation was statistically significantly, $F(2,772)=27.682, p<0.001$ values. A Scheffe post hoc test showed that for the Gen $Y$ and $Z$ groups; the effects of hedonic motivation, was statistically higher than for the Gen X group respectively, $p<0.05$ values. The mean difference (I-J) between the generation of Gen $\mathrm{Y}$ and Gen X was 0.677 , the mean difference (I-J) between the generation of Gen $Z$ and Gen $X$ was 0.685 . The Gen $Y$ and $Z$ group has a higher level of hedonic motivation compared with Gen X group.

The results revealed that the effect of generational influence on convenience motivation was statistically significantly, $F(2,772)=179.944, p<0.001$. The Scheffe post hoc test showed that the Gen $\mathrm{Y}$ and $\mathrm{Z}$ group; the influence by convenience motivation, was statistically higher than for the Gen $X$ group respectively, $p<0.001$. The mean difference $(I-J)$ between Gen $Y$ and Gen X was 1.269, the mean difference (I-J) between Gen Z and Gen X was 0.947. 
In addition, the Scheffe post hoc test revealed that the Gen Y group, influence of convenience motivation, was statistically higher than for the Gen Z, P $<0.01$. The mean difference (I-J) between Gen $Y$ and Gen $Z$ was 0.322 . These means that the Gen $Y$ group has the highest level of convenience motivation compared to Gen X and Z, and Gen X has the lowest level of convenience motivation compared to other two groups.

The results also showed that the effect of generational influence on virtual motivation was statistically significantly, since $F(2,772)=127.669, p<0.001$. Next, the Scheffe post hoc test showed that the Gen $Y$ and $Z$ group, the influence of virtual motivation, was statistically higher than the Gen $X$ group respectively, $p=0.000$. The mean difference (I-J) between Gen $\mathrm{Y}$ and Gen $\mathrm{X}$ was 1.14, the mean difference (I-J) between Gen Z and Gen X was 0.953. The Gen $\mathrm{Y}$ and $\mathrm{Z}$ have a higher level of virtual motivation compared with Gen X group.

Lastly, the results revealed that the effect of generational influence on GPI was statistically significantly, since $F(2,772)=30.901, P=0.000$. The Scheffe post hoc test showed that for the Gen $Y$ and $Z$ groups, influence of GPI, was statistically higher than the Gen $X$ group respectively, $p=0.000$. The mean difference (I-J) between Gen $Y$ and Gen $X$ was 0.617 , the mean difference (I-J) between Gen $Z$ and Gen $X$ was 0.67 . The Gen $Y$ and $Z$ have a higher level of GPI compared to Gen X group.

\section{DISCUSSION AND CONCLUSION}

This study examined the effect of consumers' motivational aspects toward green hotel selection in China. The empirical results demonstrated the existence of a direct continuous relationship between an individual's motivational variables (i.e., monetary, convenience, hedonic, and virtual motivation)/attitude/intention. This in line with many previous studies' findings (Wang \& Wong, 2020; Wang et al., 2020b) that found that attitude is one of most important determinants of an individual's intention towards green hotel selection. This study found that GPA positively affected GPI; this means that the more positive the attitude consumers have, the stronger the consumers' intentions to visit green hotels. This is important, 
because intention is the single most vital predictor of an individual's actual behavior (Wang et al., 2019). Hence, H5 was supported.

This study empirically demonstrated that monetary motivation positively influenced GPA. This corresponds to Razali et al. (2019)'s findings that found consumers in western countries are more likely to visit and willing to pay more for a green hotel. Chinese hotels' guests also expressed that they are willing to pay a premium for hotels that implement pro-environmental strategies. Thus, $\mathrm{H} 1$ was supported.

The results of this research also showed convenience motivation negatively influenced GPA. This means that consumers really think that the location of green hotels is an important factor in their decision-making process, and it seems that consumers find it difficult to find/visit green hotels in China. Hence, $\mathrm{H} 2$ was partially supported.

In contrast with findings reported by Sánchez-Ollero et al. (2014), results from his study showed a positive relationship found between hedonic motivation and GPA among green hotel consumers. Environmentally friendly hotels as a novel concept that has just been introduced in China stirred many consumers' interests, however, they still would not like to try novel products/services provided by green hotels. Thus, $\mathrm{H} 3$ was rejected. In addition, virtual motivation has a positive influence on GPA. The social media plays a vital role in influencing consumer green hotel selection, and Chinese consumers seem to trust the information/promotional messages provided by green hotels on the internet. This is corresponds to Tanford et al. (2020)'s findings that random information from social media can intervene in the booking process of a hotel. Thus, $\mathrm{H} 4$ was accepted.

Gen $\mathrm{Y}$ and $\mathrm{Z}$ consumers have a higher level of monetary motivation compared with Gen X consumers and they are more willing to pay a premium price for green hotels' products/services compared to Gen X consumers. Although hedonic motivation does not significantly influence GPA in this study, ANOVA tests showed Gen $Y$ and $Z$ consumers are more concerned about the enjoyable and playful aspects provided by green hotels compared to Gen X. Overall, Gen Z displayed a slightly higher level of monetary and hedonic motivation compared to Gen $\mathrm{Y}$. This means the young generation are more willing to try new products or 
services without consideration of price. Thus, $\mathrm{H} 6 \mathrm{a}$ and $\mathrm{H} 6 \mathrm{c}$ were accepted.

Gen $\mathrm{Y}$ consumers were found to display the highest level of convenience motivation. They display more concern on the location of a green hotel when compared with Gen X and $Z$ consumers. Gen $Y$ consumers are in their mid-20s to early 40 s, and most of them visit hotels for businesses and other similar purposes. Therefore, it is not surprising Gen $Y$ consumers are most concerned about the convenience factor when choosing green hotels. After Gen $\mathrm{Y}$, Gen $\mathrm{Z}$ consumers show the next most concern about the location of green hotels. They are not afraid to stay in a green hotel in an inconvenient place, but they need to know what facilities the hotel can provide to compensate for the inconvenience (e.g., F \& B facilities, karaoke, spa, shuttle service, spa etc.).

Generation $Y$ and $Z$ consumers are more concerned about information on green hotels obtained from the internet, such as user-generated websites, videos on social media etc. Social media plays a significant role in influencing those consumers' decision-making processes in green hotel selection. They rely greatly on other netizens' suggestions and recommendations to visit green hotels. Thus, H6d was accepted. In total, Gen $\mathrm{Y}$ and $\mathrm{Z}$ consumers displayed stronger intention to visit green hotels compared to Gen X. Thus, H6f was accepted.

\section{Theoretical Contributions}

This study is among the first to explain the relationships between different motivational aspects (i.e., monetary, convenience, hedonic, virtual motivation), GPA and GPI affecting green hotel selection. The results indicate that there is a significant causal relationship between monetary motivation (positively), convenience motivation (negatively), and virtual motivation (positively) and GPA towards green hotel selection respectively, which ultimately leads to GPI. These findings contribute to the enrichment of the hospitality and tourism literature related to the selection of environmentally friendly hotels.

Although numerous studies have investigated consumer GPB, including green hotel selection, there has been a limited number of such studies undertaken in the emerging Asian 
countries like China (Rahman et al., 2020). Research on environmentally friendly hotels is still in its preliminary stage in China, where studies revealed low levels of concern and understanding among Chinese consumers (Wang \& Wong, 2020). This study offers an alternative perspective for researchers in investigating environmentally friendly hotel selection in non-western countries, besides providing new insights on consumer motivational aspects that influence GPB.

According to Ulker-Demirel and Ciftci (2020), generational influence on GPB still seem to be an under researched area in the hospitality and tourism literature. The obtained results confirmed that there is a difference between Gen X, Y, and Z toward monetary motivation, convenience motivation, hedonic motivation, virtual motivation, and GPI. These findings clearly demonstrated the different effects of monetary motivation, convenience motivation, hedonic motivation, virtual motivation as well as GPI on different generations of Chinese hotel customers.

\section{Practical Implications}

This study provides some practical implications for environmentally friendly hotels. First, the higher price of green hotels is acceptable for most Chinese consumers, as they perceived green hotels can offer good value for money. Thus, green hotels should continue to provide exceptional quality of services to consumers with a temporary price premium as compared to traditional hotels, since monetary motivation is still the most important motivational factor influenced GPA.

With the insights on the role of hedonic motivation on selection of green hotels, Chinese consumers do not express high interests to visit them for enjoyment, entertainment, and others. This is because the concept of green hotels is still new to Chinese consumers, most of them are hesitant to visit this emerging type of hotels. Thus, green hotels' marketers should continue to promote the concept of green hotels to consumers and highlight the differences between green hotels and traditional hotels to attract people who are willing to try.

To provide more convenience for consumers is important for hotel operators to build 
hotels in assessable locations, as most Chinese consumers do not choose green hotels due to their location. Improved convenience can enable green hotel managers to market their properties more effectively. For example, the green hotels located near airports and highspeed train stations can provide shuttle service from airport/train stations to their locations. And for green hotels located elsewhere, they should provide the transportation services to/from shopping centres and tourist attractions.

Social media is an extremely important platform in China for green hotels to promote their product/service and also for customers to share their personal experiences. Green hotels must place more emphasis on their reputation and brand image on the internet. Any guests' complaints reported on the hotel's website or social media platforms must be dealt with immediately and resolved to the satisfaction of the customer as positive/negative information on the internet can spread with amazing speed.

Finally, findings from this study can be used by hotel managers to practice target segmentation and design appropriate green marketing campaigns for different generational segments. Gen $Y$ and $Z$ members should be considered high potential consumers for green hotels. Gen $\mathrm{Y}$ and $\mathrm{Z}$ consumers are more willing to pay a premium price and express a higher level of GPI to visit green hotels compared to Gen X. They are also highly concerned about the convenience factor and depend heavily on online sources of information on green hotels to make their purchase decision. Thus, hotel managers may need to select the right generations to target based on the GPB characteristics of the different generations.

\section{Limitations}

TPB is the most prevalent theory in the field of green marketing (Wang \& Wong, 2020). If the complete TPB model was to have been applied in this study, it could have provided a better understanding of the current state of intention to visit green hotels. Secondly, this study was only conducted in Xuzhou, China. Thus, the findings will only apply to this area and country, and not generalizable to other countries due to geographic and cultural differences. Hence, this study model should be replicated and tested in other countries to further confirm 
its validity and usefulness. Furthermore, some studies indicated that intention does not always translate into consumer actual purchase behavior (Wang et al., 2020a; Wang et al., 2019); therefore, future studies should focus on the individual's actual green hotel purchase behavior itself.

\section{REFERENCES}

Al-Aomar, R., \& Hussain, M. (2017). An assessment of green practices in a hotel supply chain: A study of UAE hotels. Journal of Hospitality and Tourism Management, 32, 71-81.

Bashir, S., Khwaja, M. G., Turi, J. A., \& Toheed, H. (2019). Extension of planned behavioral theory to consumer behaviors in green hotel. Heliyon, 5(12), 1-8. https://doi.org/10.1016/j.heliyon.2019.e02974

Bencsik, A., Horváth-Csikós, G., \& Juhász, T. (2016). Y and Z generations at workplaces. Journal of Competitiveness, 8(3), 90-106. https://doi.org/10.7441/joc.2016.03.06

Bilgihan, A. (2016). Gen Y customer loyalty in online shopping: An integrated model of trust, user experience and branding. Computers in Human Behavior, 61, 103-113. https://doi.org/10.1016/j.chb.2016.03.014

Burstein, D. (2011). Marketing optimization: How to determine the proper sample size. Retrieved May, 6 from https://marketingexperiments.com/a-b-testing/testing-samplesize\#comments

Byrne, B. M. (2016). Structural equation modeling with AMOS: Basic concepts, applications, and programming. Routledge. https://doi.org/10.4324/9781315757421

Dawes, J. (2008). Do data characteristics change according to the number of scale points used? An experiment using 5-point, 7-point and 10-point scales. International Journal of Market Research, 50(1), 61-77.

Fukuyama, F. (2002). Social capital and development: The coming agenda. SAIS Review, 22(1), 23-37. https://doi.org/10.1353/sais.2002.0009

Goh, E., \& Jie, F. (2019). To waste or not to waste: Exploring motivational factors of generation $Z$ hospitality employees towards food wastage in the hospitality industry. International $\begin{array}{llll}\text { Journal of Hospitality } & \text { Management, } & \text { 80, }\end{array}$ https://doi.org/10.1016/j.ijhm.2019.02.005

Green Hotel Association. (2021). What Are Green Hotels? Available: http://www.greenhotels.com

Hair, J. F., Black, W. C., Babin, B. J., \& Tatham, R. L. (2010). Multivariate data analysis: A global perspective (7th ed.). Pearson Prentice Hall.

Han, H., Kiatkawsin, K., Ryu, H. B., Jung, H., \& Kim, W. (2019). Determinants of young vacationers' recycling and conservation behavior when traveling. Social Behavior and Personality: An international journal, 47(2), 1-11. https://doi.org/10.2224/sbp.7650

Han, H., Meng, B., \& Kim, W. (2017). Emerging bicycle tourism and the theory of planned behavior. Journal of sustainable tourism, 25(2), 292-309. https://doi.org/10.1080/09669582.2016.1202955

Ho, R. (2006). Handbook of univariate and multivariate data analysis and interpretation with SPSS. CRC Press. https://doi.org/10.1201/9781420011111.ch2

Ibáñez, M. E., Ferrer, D. M., Muñoz, L. V. A., Claros, F. M., \& Ruiz, F. J. O. (2020). University as change manager of attitudes towards environment (The importance of environmental education). Sustainability, 12(11), 4568. https://doi.org/10.3390/su12114568

Ibnou-Laaroussi, S., Rjoub, H., \& Garanti, Z. (2018). Green awareness and its impact on consumers purchasing decision: Case of University students in the Turkish Republic of the Northern Cyprus 31st International Business Information Management Association 
Conference, Milan, Italy.

Jan, I. U., Ji, S., \& Yeo, C. (2019). Values and green product purchase behavior: The moderating effects of the role of government and media exposure. Sustainability, 11(23), 6642. https://doi.org/10.3390/su11236642

Jena, L. K., \& Behera, B. (2017). Environmental crisis and human well-being: A review. International Journal of Development and Sustainability, 6(8), 561-574.

Kim, Y. J., Palakurthi, R., \& Hancer, M. (2012). The environmentally friendly programs in hotels and customers' intention to stay: An online survey approach. International Journal of Hospitality \& Tourism Administration, 13(3), 195-214. https://doi.org/10.1080/15256480.2012.698169

Kline, R. B. (2015). Principles and practice of structural equation modeling (3rd ed.). Guilford.

Kumar, S., \& Sreen, N. (2020). Role of internal and external values on green purchase. In V. Naidoo \& R. Verma (Eds.), Green marketing as a positive driver toward business sustainability (pp. 158-185). IGI Global. https://doi.org/10.4018/978-1-5225-9558-8

Kusumawati, A., Listyorini, S., Suharyono, \& Yulianto, E. (2019). The impact of religiosity on fashion involvement and patronage intention among generation $X Y Z$ of Indonesian Muslim consumers. International Journal of Innovation, Creativity and Change, 9(10), 237-255.

Lew, A. A. (2020). The global consciousness path to sustainable tourism: A perspective paper. Tourism Review, ahead-of-print(ahead-of-print). https://doi.org/10.1108/TR-07-20190291

Lindenberg, S. (2001). Social rationality versus rational egoism. In J. H. Turner (Ed.), Handbook of sociological theory (pp. 635-688). Kluwer Academic/Plenum.

Lindenberg, S., \& Steg, L. (2007). Normative, gain and hedonic goal frames guiding environmental behavior. Journal of Social Issues, 63(1), 117-137. https://doi.org/10.1111/j.1540-4560.2007.00499.x

Mahmood, S., Khwaja, M. G., \& Jusoh, A. B. (2019). Electronic word of mouth on social media websites: Role of social capital theory, self-determination theory, and altruism. International Journal of Space-Based and Situated Computing, 9(1), 239-254.

Meyers, L. S., Gamst, G., \& Guarino, A. J. (2006). Applied multivariate research: Design and interpretation. Sage.

Miao, L., \& Wei, W. (2013). Consumers' pro-environmental behavior and the underlying motivations: A comparison between household and hotel settings. International Journal of Hospitality Management, 32, 102-112. https://doi.org/10.1016/j.ijhm.2012.04.008

Mohamad, Z. Z., Arifin, T. R. T., Samsuri, A. S., \& Munir, M. F. M. B. (2014). Intention to visit green hotel in Malaysia: The impact of personal traits and marketing strategy. International Journal of Business and Social Science, 5(7), 167-173. http://www.ijbssnet.com/journals/Vol_5_No_7_June_2014/19.pdf

Nimri, R., Patiar, A., Kensbock, S., \& Jin, X. (2019). Consumers' intention to stay in green hotels in Australia: Theorization and implications. Journal of Hospitality \& Tourism Research, 44(1), 149-168. https://doi.org/10.1177/1096348019862602

Oczachowska, A. (2020). Purchase behaviors of generation Y. Annales Universitatis Mariae

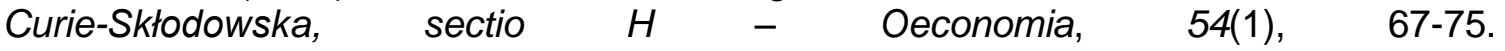
https://doi.org/10.17951/h.2020.54.1.67-75

Peng, N., \& Chen, A. (2019). Luxury hotels going green - The antecedents and consequences of consumer hesitation. Journal of sustainable tourism, 27(9), 1374-1392. https://doi.org/10.1080/09669582.2019.1622710

Puciato, D. (2020). Behavioral factors in hotel location: A study of hotels from Opole Province in Poland. Turyzm/Tourism, 30(1), 95-103. https://doi.org/10.18778/0867-5856.30.1.21

Rahman, M. S., Hossain, M. I., \& Hossain, G. M. S. (2020). Factors affecting consumers' green purchase behavior towards energy saving lights in Bangladesh: The mediating role of green purchase intention. International Journal of Information, Business and Management, 12(3), 19-37. https://doi.org/10.6007/IJAREMS/v8-i3/6625

Rajendran, S. D., Wahab, S. N., \& Singh, M. K. P. (2019). Malaysian consumers' preference for green packaging. International Journal of Society Systems Science, 11(4), 312-331. 
https://doi.org/10.1504/IJSSS.2019.103629

Razali, N. A. M., Shahril, A. M., Rahim, M. A., \& Samengon, H. (2019). Eco-friendly attitude and response behaviors of green hotel guest in Malaysia. Journal of Tourism, Hospitality and Environment Management, 4(13), 77-89.

Rezaei, S., Ali, F., Amin, M., \& Jayashree, S. (2016). Online impulse buying of tourism products: The role of web site personality, utilitarian and hedonic web browsing. Journal of Hospitality and Tourism Technology, 7(1), 60-83. https://doi.org/10.1108/JHTT-032015-0018

Sánchez-Ollero, J. L., García-Pozo, A., \& Marchante-Mera, A. (2014). How does respect for the environment affect final prices in the hospitality sector? A hedonic pricing approach. Cornell Hospitality Quarterly, 55(1), 31-39. https://doi.org/10.1177/1938965513500709

Sarmah, H. K., Hazarika, B. B., \& Choudhury, G. (2013). An investigation on effect of bias on determination of sample size on the basis of data related to the students of schools of Guwahati. International Journal of Applied Mathematics and Statistical Sciences, 2(1), 3348. https://iaset.us/archives?jname=45_2\&year=2013\&submit=Search

Saunders, M., Lewis, P., \& Thornhill, A. (2011). Research methods for business students (5th ed.). Pearson Education.

Sekaran, U. (2006). Research methods for business: A skill building approach. John Wiley \& Sons.

Sniehotta, F. F., Presseau, J., \& Araújo-Soares, V. (2014). Time to retire the theory of planned behavior. Health Psychology Review, 8(1), 1-7. https://doi.org/10.1080/17437199.2013.869710

Sutikno, V., Indarini, \& Margaretha, S. (2020). Young consumer's purchase intention toward environmentally friendly products in Indonesia: Expanding the theory of planned behavior. Advances in Economics, Business and Management Research, 115, 36-40. https://doi.org/10.2991/aebmr.k.200127.008

Tabachnick, B. G., \& Fidell, L. S. (2012). Using multivariate statistics (6th ed.). Allyn \& Bacon/Pearson Education.

Tan, L. L., Abd Aziz, N., \& Ngah, A. H. (2020). Mediating effect of reasons on the relationship between altruism and green hotel patronage intention. Journal of Marketing Analytics, 8(1), 18-30. https://doi.org/10.1057/s41270-020-00067-7

Tanford, S., Kim, M., \& Kim, E. J. (2020). Priming social media and framing cause-related marketing to promote sustainable hotel choice. Journal of sustainable tourism, 28(11), 1762-1781. https://doi.org/10.1080/09669582.2020.1760287

Teng, Y.-M., Wu, K.-S., \& Chou, C.-Y. (2020). Price or convenience: What is more important for online and offline bookings? A study of a five-star resort hotel in Taiwan. Sustainability, 12(10), 3972. https://doi.org/10.3390/su12103972

Testa, F., Pretner, G., lovino, R., Bianchi, G., Tessitore, S., \& Iraldo, F. (2020). Drivers to green consumption: A systematic review. Environment, Development and Sustainability, ahead-of-print(ahead-of-print), 1-55. https://doi.org/10.1007/s10668-020-00844-5

Ulker-Demirel, E., \& Ciftci, G. (2020). A systematic literature review of the theory of planned behavior in tourism, leisure and hospitality management research. Journal of Hospitality and Tourism Management, 43, 209-219. https://doi.org/10.1016/j.jhtm.2020.04.003

Wang, L. (2020). Determinants of consumers purchase attitude and intention toward green hotel selection. Journal of China Tourism Research, ahead-of-print(ahead-of-print), 1-20. https://doi.org/10.1080/19388160.2020.1816241

Wang, L., \& Wong, P. P. W. (2020). Marketing of environmentally friendly hotels in China through religious segmentation: A theory of planned behavior approach. Tourism Review, ahead-of-print(ahead-of-print), 1-16. https://doi.org/10.1108/TR-08-2019-0327

Wang, L., Wong, P. P. W., \& Elangkovan, N. A. (2020a). Antecedents of green purchase behavior: An examination of altruism and environmental knowledge. International Journal of Culture, Tourism and Hospitality Research, 14(1), 63-82. https://doi.org/10.1108/lJCTHR-02-2019-0034

Wang, L., Wong, P. P. W., \& Elangkovan, N. A. (2020b). The demographic impact of consumer green purchase intention toward green hotel selection in China. Tourism and Hospitality 
Research, 20(2), 210-222. https://doi.org/10.1177/1467358419848129

Wang, L., Wong, P. P. W., \& Elangkovan, N. A. (2020c). The influence of religiosity on consumer's green purchase intention towards green hotel selection in China. Journal of China Tourism Research, 16(3), 319-345. https://doi.org/10.1080/19388160.2019.1637318

Wang, L., Wong, P. P. W., Elangkovan, N. A., \& Chee, W. M. (2019). Green hotel selection of Chinese consumers: A planned behavior perspective. Journal of China Tourism Research, 15(2), 192-212. https://doi.org/10.1080/19388160.2018.1553743

Wiratno, B., Priyomarsono, N. W., Trisno, R., \& Lianto, F. (2020, 2020/05/20). Shopping centre evolution in Jakarta due to changes of generation $X Y Z$ consumerism behavior. Tarumanagara International Conference on the Applications of Social Sciences and Humanities (TICASH 2019), Universitas Tarumanagara, Jakarta, Indonesia.

Yang, Y., Wong, K. K. F., \& Wang, T. (2012). How do hotels choose their location? Evidence from hotels in Beijing. International Journal of Hospitality Management, 31(3), 675-685. https://doi.org/10.1016/j.ijhm.2011.09.003

Ye, Q., Law, R., Gu, B., \& Chen, W. (2011). The influence of user-generated content on traveler behavior: An empirical investigation on the effects of e-word-of-mouth to hotel online bookings. Computers in Human Behavior, 27(2), 634-639. https://doi.org/10.1016/j.chb.2010.04.014

Yeo, V. C. S., Goh, S.-K., \& Rezaei, S. (2017). Consumer experiences, attitude and behavioral intention toward online food delivery (OFD) services. Journal of Retailing and Consumer Services, 35, 150-162. https://doi.org/10.1016/j.jretconser.2016.12.013

Zahan, I., Chuanmin, S., Fayyaz, M., \& Hafeez, M. (2020). Green purchase behavior towards green housing: An investigation of Bangladeshi consumers., ahead-of-print(ahead-ofprint), 1-13. https://doi.org/10.1007/s11356-020-09926-3

Zolait, A. H. S., \& Sulaiman, A. (2009). The influence of communication channels on internet banking adoption. Asian Journal of Business and Accounting, 2(1\&2), 115-134. https://doi.org/10.1.1.470.7874 